\title{
THE LIMINAL IDENTITY OF A TRANSYLVANIAN CITY. "THE URBANISTIC EVOLUTION OF INTERWAR CLUJ". A REVIEW
}

\author{
Sebastian IONESCU \\ Technical University, Cluj-Napoca, Faculty of Architecture and Urban Planning, ROMANIA \\ sebastian.ionescu@arch.utcluj.ro
}

Evoluţia urbanistică a Clujului interbelic [The Urbanistic Evolution of Interwar Cluj] / Vlad Sebastian RUSU; Editura Academia Română. Centrul de Studii Transilvane, 2015; 248 p.

ISBN 978-606-8694-07-8

DOI: http://dx.medra.org/10.23740/TID120166

\section{INTRODUCTION}

In contemporary politically convulsive times, when the discourse on ethnically grounded nations is being reconsidered, because of processes like migration, studies that bespeak of national identity are somehow "fresh" and "popular" by default. After Brexit, voices that demand reviewing the territorial transfers after the Second World War bring the contested region of Romania, Transylvania, once again in the spotlights.

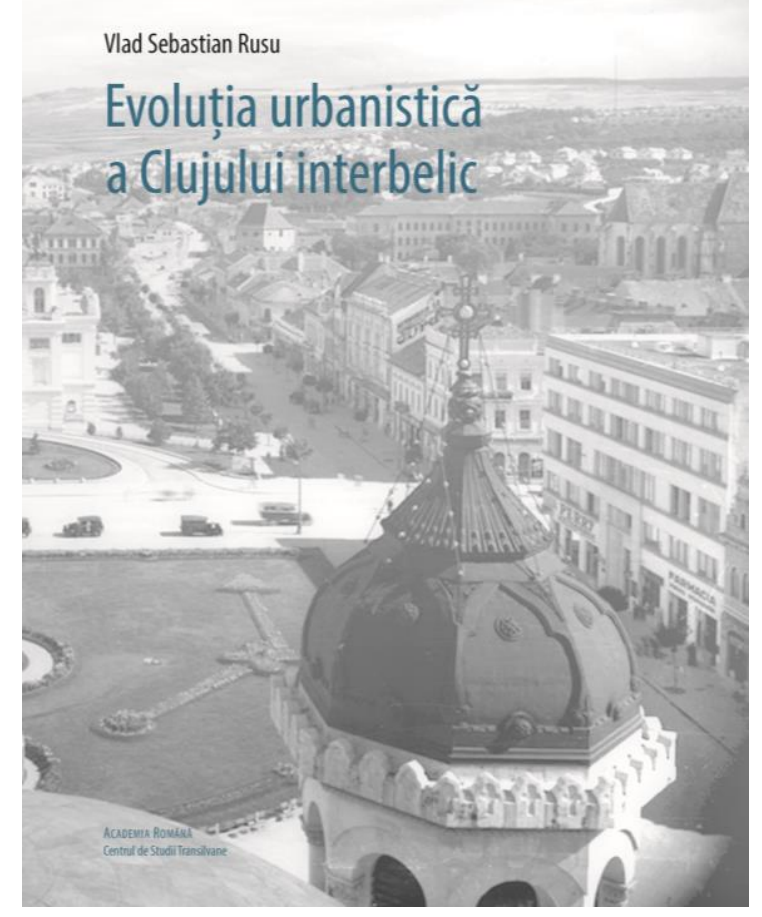

The 2015 book entitled "The Urbanistic Evolution of Interwar Cluj", written by PhD. Arch. Vlad Sebastian Rusu, portrays the capital of this mythological land in a transition state, between the World Wars. The year 1918 is the moment when the "Great Romania", meaning the Romanian National State, was assembled by appropriating - among other regions Transylvania, a territory that has been part of Hungary for more than 1,000 years. This time lapse analysed in the book spans over two decades, between 1918 and 1940, when the Romanian administration substituted the Austrian-Hungarian one. The author's main observations capture the continuity that characterises this threshold era engaging in an arhitectural and urbanistic point of view. Another potrayed aspect is the insertion of a somehow external identity and culture into a liminal territory.

As rendered in its predecessor text which this book partial deepens and extends, that belonging to Prof. PhD. Arch. Mihaela Ioana Maria Agachi, "Modern Cluj. Urbanistic Aspects" (2009), Mr. Rusu sees the Interwar Cluj as a city of contrasts, a kind of a "Balkan Burg". Although the ideas 
of coherence and harmony were stated above, here is an enumeration of contradictions that were to be found at the time: between the newest factories and plants and the craftsmen athmosphere, between the slums on the Cetățuie Hill and the nearby elegant villas on the Gruia Hill. Shortly: fractures of scale, proximity contrasts between rural and urban characters. When talking about the whole European context post World War I, the author once again places Cluj between more or less opposite poles: between the Garden City of Ebenezer Howard and the Industrial City of Tony Garnier, between the progressist and culturalist models, terms coined by Françoise Choay, between the traditionalist architecture of local Hungarian ethnics and the modernist avangarde style imported from Bucharest mainly, and so on. Still, there can be traced throughout the studied time lapse a concerted direction towards unification, but not fully negating the idea of diversity. Anyhow, this fact does not stand as a major contradiction, as it will be seen here.

\section{IN PROCESS}

In analysing the evolution of Cluj before and around 1918, Mr. Rusu, still grounding his sight in the previous European fashion, mentions the demolition of the medieval fortifications to create new streets or representative spaces, like in Vienna. Still, what the author detects in an original way and proves systematicaly is its suburban sprawling feature. And here comes the surprise climax: Cluj has never had - before World War I and the Interwar period - what we call today a general development masterplan. Its organic character has prevailed over centuries, hence its charm. The morphology of the city plan evolves from a tentacular shape, via a radial concentric form, to the present linear East-West orientation. The Someș River and the railways, two major barriers and guidelines, gave the city its final contemporary shape. Other than these physical determinants, a vast plethora of different - but intricately interrelated - factors shaped the changing of both the structure and image of the city, as closely analysed by the author: the new Romanian administration apparatus, the major expansion of the city's hinterland combined with a doubling of the population, the new law concerning agriculture, the economic growth, the involvement of organisational entities like the new "Regele Ferdinand I" University, etc.

The "corset" of regulations - urban division, building permits and sanctions, together with a precise topographical map of Cluj imposed some order upon the heterogeneous existing urban texture. Densification was used as the main tool for action in structuring, defining the three urban zones - central (the medieval core), peri-central, and industrial. The urban zoning mainly maintained the previous four zones: education, loisir, industrial, and comercial/trade. A key relation discovered by the author is the fusion between the education and loisir zones. This operation led to the regional integration of the natural landscape and prefaced the "learn and play" credo of today. The Sports Park, for instance, which was seen as a place of integration and inclusion where "people of all ages, of all professions and conceptions, under the tonic influence of the natural factors should merge into an amalgam of health and happiness all their apparent differences" (Hațieganu, quoted by Rusu, 2015, p. 119). More illustrative examples for the above mentioned fusion are the following: the Botanical Garden, which initially was not supposed to be a park, and the Ethnographic Museum, which was imagined as "the nation's garden", but hosting also the artefacts of the coinhabiting ethnics and neighbouring nations.

Putting aside the scientific discourse, Mr. Rusu slightly renders some of the main figures that conducted and sometimes created together with the architects in charge: the doctor luliu Hațieganu, the botanist Alexandru Borza and the ethnologist Romulus Vuia. Those were the kind of people that could have been living in the new luxurious garden suburbs like Andrei Mureșanu 
or Donath, which were created at the time, inspired probably by the work of Raymond Unwin. However, the issue of social housing was not neglected, the models spawned by social aware countries like England, France, and Germany were to be adapted with pragmatism, but also with great care.

Somehow part of the new Romanian "colonisation" meant the descentration of the Unirii Square, the main large square during the Austrian-Hungarian reign. Of course, the amplification of the other new formed extramural squares and the change of the street grid began before 1918. But in the nowadays Avram lancu Square, the nationalist Geist was strongly emphasized, mainly through the construction of the Orthodox Cathedral, the most important building of the Interwar period in Cluj. Of course, being a subject regarding architectural styles, the issue has been already tackled by others, like Mihaela Criticos (2010) for example. What is striking obvious when "reading" the modernist buildings implanted in Cluj through the beautifully redrawn plans in Mr. Rusu's book is their timeless classicism. With few exceptions, for most of them the conception is classical, symmetrical, aside from the austere facade expression and the horizontally dominant, modernist features. Once again the continuity has been proved. A unique Bauhaus church, the Tătaru Villa (build by the world famous modernist architect Gio Ponti), but also fine Hungarian folk style samples (Villa Moll Elemér), or the Neo-Romanian style Villa Munteanu, all these outstanding examples stand as witnesses for a marvelous confluence between multiple geographies. In contrast to the apologetic depiction of the recent past, Mr. Rusu in very critical about the new extensions that parasite their noble forefathers.

What adds extra flavour to the text is the insertion of humorous stories, but added not for free. The example of a contest for building a bridge over the Someș River is relevant both for the praised idea of public contest at the time - repeatedly reported by the author as a quality - and for the "political ping-pong" between the ethnies. The competition was won by an Austrian Hungarian duo, a team that used as a contest code the purest Daco-Romanian name "Decebal" and "quoted" in their design typical Romanian folk ornaments.

Releated to my personal experience, I discovered a very refined portrayal of the modernist architecture influenced by the Italian Rationalist Movement (the so called "Mussolini Style"), belonging to architects - personal preferences - like George Cristinel and Duiliu Marcu.

As a critique, I partial disagree with the author's presentation of the "haussmann"-isation of Paris as something generally desirable for all cities, including Cluj. It is true that the metropolitan image and structure of Paris, or even of Bucharest and of lași, could not have been reached without such a surgical process. But the organic medieval core is valuable content, together with its land survey. In extramuroscan be imagined such ultra urban structures, like the Avram lancu or Mihai Viteazul squares for example.

The book has intentionally left out for further research perhaps - although the link is mentioned - a study of the urban planning models to be found in Wallachia at the time, mainly of French descent, which were supposed to be exported to Transylvania and therefore Cluj. A reference or a comparison to the book referring to the parceling of loanid Park in Bucharest by Christina Woinaroski (2013) could have been illustrative for this process.

\section{CONCLUSIONS}

The book written by Vlad Rusu is illustrative for the term "synchronism" introduced and theorised in the Romanian culture of the Interwar years by the literary critic and sociologist Eugen Lovinescu. Obviously, the term is referring to the synchronising of the Eastern European 
cultures with the Western ones. Still, in order to colour up the uniformity of this architectural Esperanto, modernism, Eugen Lovinescu called later for a "style" that was to be national in essence and international in substance. Such a synthesis is captured vividly by the architect Vlad Sebastian Rusu in describing the Interwar Cluj, regarding both architecture and urban evolution, a city placed at the intersection of Romanian, Hungarian, German/Austrian, Jewish and French cultures. The platonic Ideals of continuity (some of the ideas conceived back then spawned contemporary projects), harmony, order, measure, coherence that generated the Interwar Cluj are accurately and systematically proven all along the narrative line. Because, in the end, the book is a story, a very colourful one, standing as the seal of an eclectic city like Cluj, with a avant la lettre postmodern multiple identity, a multiplicity that does not exclude unity.

\section{REFERENCES}

AGACHI, M.I.M. (2009). Clujul modern: aspecte urbanistice [The Modern Cluj: Urbanistic Aspects]. Cluj-Napoca: U.T. Press.

CRITICOS, M. (2010). Art Deco sau modernismul bine temperat [Art Deco or Moderate Modernism]. Bucharest: Simetria.

RUSU, V.S. (2015). Evoluția urbanistică a Clujului interbelic [The Urbanistic Evolution of Interwar Cluj]. Cluj-Napoca: Editura Academia Română. Centrul de Studii Transilvane.

WOINAROSKI, C. (2013). Istorie Urbană. Lotizarea și Parcul loanid din București în context european [Urban History. Parceling and loanid Park from Bucharest in a European Context]. Bucharest: Simetria. 